\title{
Screening for antifungal, DNA-damaging and anticholinesterasic activities of Brazilian plants from the Atlantic Rainforest - Ilha do Cardoso State Park
}

\author{
Elaine Monteiro Cardoso-Lopes, ${ }^{1}$ Rosana Cristina Carreira, ${ }^{1}$ Débora Gomes Agripino, ${ }^{1}$ \\ Luce Maria Brandão Torres, ${ }^{1}$ Inês Cordeiro, ${ }^{1}$ Vanderlan da Silva Bolzani, ${ }^{2}$ Sônia Machado \\ de Campos Dietrich, ${ }^{1}$ Maria Claudia Marx Young*,1 \\ ${ }^{1}$ Instituto de Botânica, CP 3005, 01061-970 São Paulo-SP, Brazil, \\ ${ }_{2}^{2}$ Instituto de Química, Universidade Estadual Paulista, CP 355, 14800-900 Araraquara-SP, Brazil
}

\begin{abstract}
RESUMO: “Avaliação das atividades antifúngica, no reparo do DNA e anticolinesterásica de plantas Brasileiras da Mata Atlântica - Parque Estadual da Ilha do Cardoso”. Extratos brutos de 17 espécies de plantas coletadas em região de Mata Atlântica no Estado de São Paulo (Brasil) foram avaliadas para as atividades: antifúngica, no reparo do DNA e inibição da acetilcolinesterase. Dos 34 extratos obtidos de folhas e galhos das plantas analisadas para a atividade antifúngica com Cladosporium sphaerospermum e C. cladosporioides, 26,5\% foram ativos. Todavia, apenas o extrato das folhas de Cabralea canjerana inibiu fortemente o crescimento dos dois fungos. No ensaio de reparo do DNA com linhagens mutantes de Saccharomyces cerevisiae, 11,7\% dos extratos foram ativos, sendo que, $100 \%$ destes foram seletivos para o mecanismo de reparo do DNA envolvendo topoisomerase II. Das 17 espécies analisadas, 12 demonstraram atividade anticolinesterásica no ensaio qualitativo sobre cromatografia de camada delgada (CCD). No entanto, apenas os extratos de Tetrastylidium grandifolium (galhos) e Sloanea guianensis (folhas e galhos) apresentaram atividade anticolinesterásica maior que 50\% no ensaio quantitativo.
\end{abstract}

Unitermos: Floresta Mata Atlântica, atividade antifúngica, inibidores da acetilcolinesterase, triagem de plantas.

\begin{abstract}
Crude extracts from 17 plant species collected from an Atlantic Forest region in the State of São Paulo (Brazil) have been screened for antifungal, DNA-damaging and acetylcholinesterase inhibiting activities. Of the 34 extracts obtained from leaves and stems of plants assayed for antifungal activity with Cladosporium sphaerospermum and C. cladosporioides 26.5\% were active. However, only the extract of leaves of Cabralea canjerana showed a strong inhibition of both fungi. The DNA-damaging assay with mutant strains of Saccharomyces cerevisiae resulted in $11.7 \%$ of the extracts being active whereas $100 \%$ of them showed selectivity for the DNA-repair mechanism of topoisomerase II. Of the 17 species analysed, 12 showed anticholinesterasic activity in TLC assay. However, only extracts from Tetrastylidium grandifolium (stems) and Sloanea guianensis (leaves and stems) inhibited acetylcholinesterase activity more than $50 \%$ in quantitative assay.
\end{abstract}

Keywords: Atlantic Rainforest, antifungal activity, acetylcholinesterase inhibitors, plant screening.

\section{INTRODUCTION}

The Atlantic Rainforest is considered one of the priorities for conservation of biodiversity in the American Continent (Myers et al., 2000). Today, the Atlantic Forest is restricted to ca $98.800 \mathrm{~km}^{2}$ of remnants, i.e. $7.6 \%$ of its original extension. This complex biome extends for more than 17 Brazilian States, displaying several phytophysiognomies determined by coastal proximity, relief, types of soil and pluviometric regimes (Rizzini, 1979). Very few surveys of medicinal plants have been performed in areas of Mata Atlântica as well as in other Brazilian biomes such as "Caatinga",
"Pantanal" and "Cerrado" (Vieira, 1999). Recently, an ethnobotanical survey has been performed in rural and urban areas of three cities located in the Atlantic forest region of the State of São Paulo in which 628 medicinal uses were described for 114 plant species. The survey demonstrated that the majority of the plants were employed for respiratory and gastrointestinal diseases and as analgesics. The majority of the plants cultivated for medicinal usage were exotic (Di Stasi et al., 2002).

Natural products research employs a number of relevant bioassays in order to find out biologically active chemicals. For the initial screening of crude extracts, simple, rapid, inexpensive bioassays with good 
reproducibility are used. These bioassays generally require a small amount of sample. Methods using thinlayer chromatography (TLC) bioautography which possess good compatibility with a large number of samples have many utility to screening extracts (Marston et al., 2002).

A vast number of native Brazilian plant species have not yet been chemically or biologically evaluated, the interdisciplinary BIOTA/SP program "Conservation and Utilization of São Paulo Biodiversity" has been assembled aiming at description of the biodiversity in the State in terms of taxonomy and biological properties. The project "Conservation and sustainable use of the diversity from Cerrado and Atlantic Forest: chemical diversity and prospecting for potential drugs" aims at searching lead-containing molecules from plant species occurring in the State of São Paulo, especially in the "Cerrado" and Atlantic Forest. The project was conceived to identify antioxidant, anti-inflammatory, antifungal, anticancer, antimalarial and acetylcholinesterase inhibiting lead- containing compounds from plant species of these biomes (www.biota.org.br). Following the objectives of this project, crude extracts from leaves and stems of Atlantic Forest plants were screened for antifungal, DNA-damaging and acetylcholinesterase inhibiting activities.

\section{MATERIAL AND METHODS}

\section{Study area}

The Ilha do Cardoso with 22.500 ha is situated in the Cananéia municipality, State of São Paulo, Brazil $\left(25^{\circ} 03^{\prime} 05^{\prime \prime}-25^{\circ} 18^{\prime} 18^{\prime \prime} \mathrm{S}\right.$ and $47^{\circ} 53^{`} 48^{\prime \prime}-48^{\circ} 05^{\prime} 42^{\prime}$ $\mathrm{W})$. The island is largely mountainous; the central region is dominated by a massif of over $800 \mathrm{~m}$, composed of metamorphic rocks (gneisses and micaschists) with magmatic outcrops (granites). Climate is megathermic, superhumid, with no water shortage and considerable excess in summer. Average annual temperature is 21.2 ${ }^{\circ} \mathrm{C}$ (Fiuza de Mello and Mantovani, 1994). It might be said that the Ilha do Cardoso offers a sample of all vegetation types occurring along the coast of Brazil: pioneer dune vegetation, "restinga" vegetation, coastal plain rainforest, Serra do Mar tropical rainforest and mangrove (Barros et al., 1991).

\section{Plant material}

The plants analyzed were collected in Ilha do Cardoso, in June 2002, identified and a voucher specie of each was deposited at the Herbarium (SP) of the Instituto de Botânica de São Paulo, Brazil.

\section{Preparation of the extract}

The plants were dried in the shadow at room temperature. The dry material was separated (stems and leaves) and ground. The ground material (30-60 g) was extracted with $60-80 \mathrm{~mL}$ ethanol $92^{\circ} \mathrm{GL}$ in an automatic extractor (ASE 300, Dionex) at $70{ }^{\circ} \mathrm{C}$ with an extraction cycle of 15 min. The extracts were concentrated under vacuum in a rotatory evaporator and dried in a steam bath at $50{ }^{\circ} \mathrm{C}$. The yields varied from 2-10 g.

\section{Biological assays by TLC bioautography}

\section{Antifungal activity}

Cladosporium cladosporioides (Fresen) de Vries SPC 140 and Cladosporium sphaerospermum Penzig (SPC 491) from the live collection of the Instituto de Botânica. were grown in potato dextrose agar for 12 days until sporulation. Ten microliters of a solution corresponding to $400 \mu \mathrm{g}$ of crude extracts were applied on Al-backed silica Gel GF ${ }_{254}$ TLC layers (Merck) and run with $\mathrm{CHCl}_{3}: \mathrm{MeOH}(9: 1 \mathrm{v} / \mathrm{v})$. The solvent was then completely removed and the plates were sprayed with a spore suspension of either $C$. sphaerospermum or $C$. cladosporioides in a glucose and salt solution (Homans and Fuchs, 1970; Rahalison et al., 1994) and incubated for $48 \mathrm{~h}$ at $28{ }^{\circ} \mathrm{C}$. After incubation, clear inhibition zones appeared against the dark background of the chromatogram. Nystatin $(1.0 \mu \mathrm{g})$ and miconazole $(0.5$ $\mu \mathrm{g})$ were used as standards.

\section{Acetylcholinesterase activity}

The procedure recently reported by Marston et al. (2002) was used for this bioassay. Briefly, acetylcholinesterase type V (Sigma, product no. C 2888, $1000 \mathrm{U}$ ) was dissolved in Tris-hydrochloric acid buffer (pH 7.8) and stabilized by the addition of bovine serum albumin fraction V (0.1\%, Sigma, product no. A-4503). TLC layers were spotted with $200 \mu \mathrm{g} /$ spot of plant extract and galanthamine (Sigma, $1 \mu \mathrm{g} / \mathrm{spot}$ ) and eserine (Sigma, $0.3 \mu \mathrm{g} / \mathrm{spot}$ ) were used as positive controls. TLC layers were developed with $\mathrm{CHCl}_{3}: \mathrm{MeOH}(9: 1 \mathrm{v} / \mathrm{v})$ and subsequently dried. The plates were then sprayed with the enzyme solution $(6.66 \mathrm{U} / \mathrm{ml})$, thoroughly dried and incubated at $37{ }^{\circ} \mathrm{C}$ for $20 \mathrm{~min}$ (moist atmosphere). Enzyme activity was detected by spraying with a solution consisting of $0.25 \%$ of 1-naphtyl acetate in EtOH (5 ml) plus $0.25 \%$ aqueous solution of Fast Blue B salt (20 $\mathrm{ml})$. Potential acetylcholinesterase inhibitors appeared as clear zones on a purple colored background.

\section{Microplate assay}

The method used is extremely sensitive and is applicable to low concentrations of enzyme. The principle of the method is the measurement of the rate of production of thiocholine as acetylthiocholine is hydrolyzed. This is accomplished by the continuous 
reaction of the thiol with 5,5'-dithiobis-2-nitro-benzoic acid (Ellman et al., 1961).

Acetylcholinesterase activity was measured using a 96-well microplate reader (Rhee et al,. 2001) based on Ellman's method (Ellman et al., 1961). In this method the enzyme hydrolyzes the substrate acetylthiocholine resulting in the production of thiocholine which reacts with 5,5'-dithio-bis(2-nitrobenzoic acid) (DTNB) to produce 2-nitrobenzoate-5-mercaptothiocholine and 5-thio-2-nitrobenzoate which can be detected at $405 \mathrm{~nm}$. In the 96-well plates, $25 \mu \mathrm{l}$ of $15 \mathrm{mM}$ acetylthiocholine iodide (ATCI) in water, $125 \mu \mathrm{l}$ of $3 \mathrm{mM}$ DTNB in buffer C, $50 \mu \mathrm{l}$ of buffer B, $25 \mu \mathrm{l}$ of plant extract sample (10 $\mathrm{mg} / \mathrm{mL}$ in $\mathrm{MeOH}$ diluted ten times with buffer $\mathrm{A}$, to give a concentration of $1 \mathrm{mg} / \mathrm{mL}$ ) were added and the absorbance was measured at $405 \mathrm{~nm}$ every $30 \mathrm{~s}$ for three times. Then $25 \mu \mathrm{l}$ of $0,22 \mathrm{U} / \mathrm{mL}$ of the enzyme were added and the absorbance was again read every $10 \mathrm{~min}$ for two times. Any increase in absorbance due to the spontaneous hydrolysis of the substrate was corrected by subtracting the rate of the reaction before the addition of the enzyme from the rate of the enzyme reaction. The percentage of inhibition was calculated by comparison with the rates for the sample to a blank $(10 \% \mathrm{MeOH}$ in Buffer A). The following buffers were used. Buffer A: $50 \mathrm{mM}$ Tris-HCl, $\mathrm{pH}$ 8; buffer B: $50 \mathrm{mM}$ Tris-HCl, $\mathrm{pH}$ 8, containing $0.1 \%$ bovine serum albumin $\mathrm{V}$ fraction (BSA); buffer C: 50 mM Tris-HCl, $\mathrm{pH}$ 8, containing 0.1 $\mathrm{M} \mathrm{NaCl}$ and $0.02 \mathrm{M} \mathrm{MgCl}_{2} \cdot 6 \mathrm{H}_{2} \mathrm{O}$.

\section{DNA-Damaging assay}

Due to the large number of extracts that required testing, a pre-screen using strains of topoisomerasedeficient Saccharomyces cerevisiae (Rad52Y, topoisomerase I, and RS321N, topoisomerase II) was conducted by means of an agar well diffusion assay. Provided there is no inhibition of growth of the wild type (RAD+) strain, differential inhibition of growth in any of the mutant strains (Rad52Y or RS321N) acts as an indicator of DNA-damaging activity (Gunatilaka et al., 1992).

Individual strains of yeast were seeded onto $2 \%$ of YPD (Yeast extract, Peptone and Dextrose) agar plates. Samples of plant extracts were solubilized in 1:1 DMSO-MeOH to a concentration of $4 \mathrm{mg} / \mathrm{ml}$ and 100 $\mu \mathrm{l}$ were placed in agar wells made by the removal of 6-mm plugs from agar plates containing media. Activity was measured as the diameter of the zone $(\mathrm{mm})$ of inhibition around each well. Camptothecin $(5 \mu \mathrm{g} / \mathrm{ml})$ and streptonigrin $(4 \mu \mathrm{g} / \mathrm{ml})$ were used as positive controls for the strains Rad 52Y and RS321, respectively.

Results from bioautographic assays were expressed as reference values (Rf) of zones of growth inhibition for antifungal activity and inhibition zones that measure acetylcholinesterase inhibition and photographed using an Epson Photo PC 3000 Z Mod G
790A and Camag Reprostar 3 System.

The quantitative results of acetylcholinesterase inhibition were represented as means of one typical experiment performed in triplicate. The values were analysed with the program GraphPad Prism Software, San Diego CA, version 3.0.

\section{RESULTS AND DISCUSSION}

To screen a diverse number of natural products, an effective and fast assay system is needed. In this work 34 extracts were screened for antifungal, AChE inhibitors and antitumoral activities, aiming at finding others compounds with not much side effects and good therapeutic profile.

The results of this screening are summarized in Table 1. From the 34 extracts assayed for antifungal activity with the filamentous fungi Cladosporium sphaerospermum and C. cladosporioides, nine species showed a positive moderate to strong response to either one or for both species of fungi. From the 17 plant species evaluated, the extracts from leaves of Tetrastylidium grandifolium and Phyllocalyx membranaceus showed activity only against $C$. cladosporioides.

Antifungal activity against $C$. sphaerospermum was only observed in the leaves of Brosimum guianense and in the stems of Platymiscium floribundum, Endlicheria paniculata and Guatteria australis.

Of 17 species extracts tested, only Myrsine umbellata (leaves), Cabralea canjerana (leaves) and Roupala paulensis (leaves) showed positive response against both fungi Cladosporium sphaerospermum and C. cladosporioides.

The isoflavonoids 7-hydroxy-6,4dimethoxy-isoflavonequinone, 2-hydroxy6,4,6,4-tetramethoxy-[7-O-7]-bisisoflavone, and seven other known flavonoids, 3-hydroxy-9methoxypterocarpan (medicarpin), 3,10-dihydroxy9-methoxypterocarpan, 3,9-dimethoxypterocarpan (homopterocarpin), 2,3,9-trimethoxypterocarpan, 3,4-dihydroxy-9-methoxypterocarpan (vesticarpan), 2,4,4-trihydroxychalcone (isoliquiritigenin), and 7,4dihydroxyflavanone (liquiritigenin) were isolated from the heartwood of Platymiscium floribundum. The flavonoids homopterocarpin, vesticarpan and liquiritigenin showed cytotoxic activity against five human cancer cell lines in vitro (Falcão et al., 2005). From the trunk of Platymiscium floribundum were isolated five pterocarpans: (+)-2,3,9-trimethoxypterocarpan, (+)-3,9-dimethoxypterocarpan [(+)-homopterocarpin], (+)-3,10-dihydroxy-9-methoxypterocarpan, (+)-3,4dihydroxy-9-methoxypterocarpan [(+)-vesticarpan] and $(+)$-3-hydroxy-9-methoxypterocarpan [(+)-medicarpin]. All tested compounds showed strong antimitotic effects on sea eggs assay, the (+)-2,3,9-trimethoxypterocarpan was the most active (Militão et al., 2005). The compounds (+)-2,3,9-trimethoxypterocarpan and 


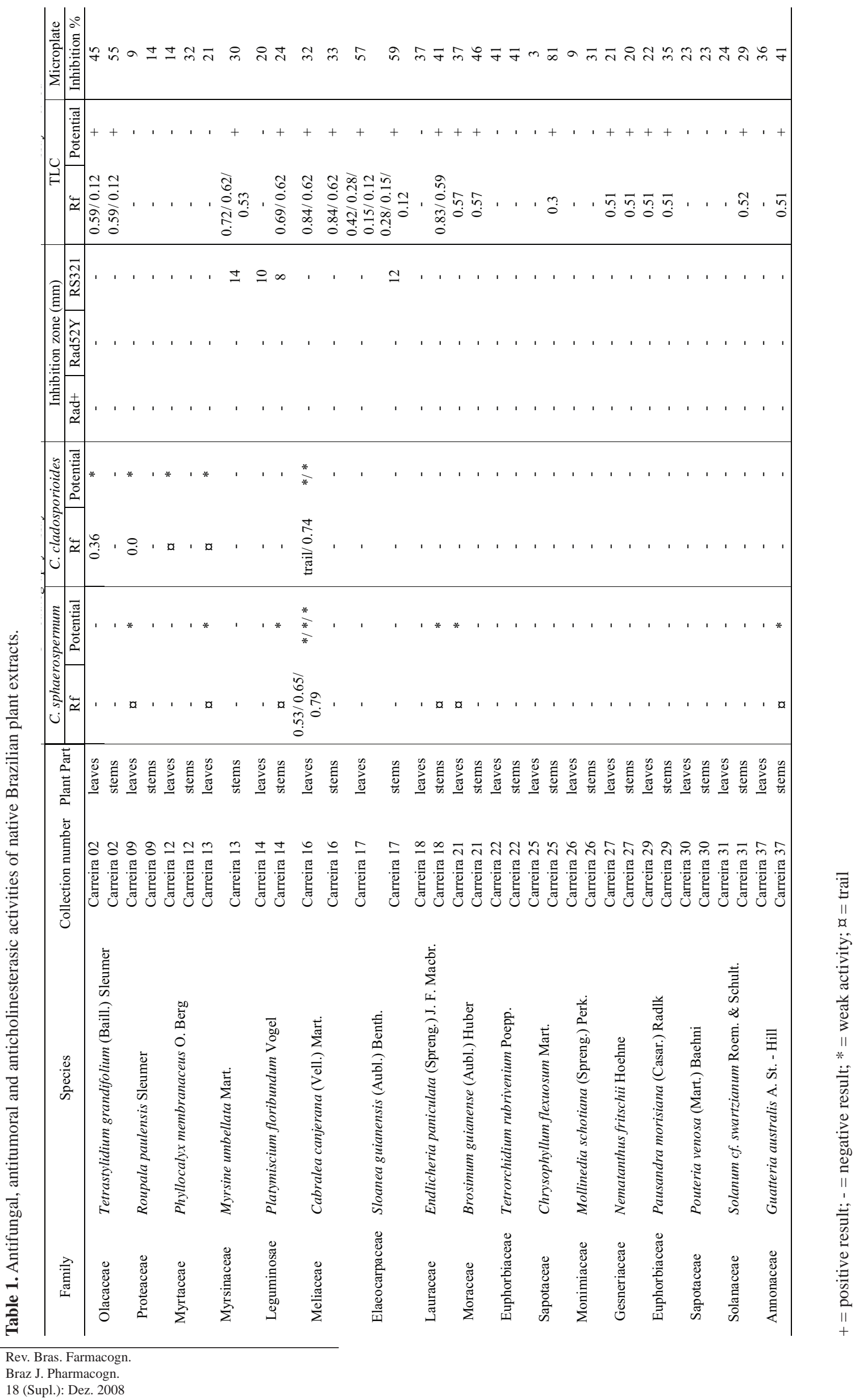


(+)-3,9-dimethoxypterocarpan [(+)-homopterocarpin $]$ induce necrosis while $(+)-3,4$-dihydroxy-9methoxypterocarpan [(+)-vesticarpan $]$ and (+)-3-hydroxy-9-methoxypterocarpan [(+)-medicarpin] trigger apoptosis in HL-60 human leukemia cells (Militão et al., 2006). Trevisan and Macedo (2003) in a recent study with Brazilian plants showed good results against acetylcholinesterase inhibition for the species Amburana cearensis, Lippia sidoides, Paullinia cupana, Solanum asperum and Plathymiscium floribundum.

The DNA-damaging assay with mutant strains of $S$. cerevisiae resulted in $11.7 \%$ active extracts (inhibition zone $\geq 8 \mathrm{~mm}$ ) with selectivity for the DNA-repair mechanisms of topoisomerase II. The four active extracts from three species, were selective for topoisomerase II (Myrsine umbellata (stems), Platymiscium floribundum (leaves and stems) and Sloanea guianensis (stems).

The remarkable number of flavonoids isolated from Platymiscium floribundum may be responsible for antifungal and DNA-damaging activities, since $P$. floribundum showed strong cytotoxic activity (Militão et al., 2005; Militão et al., 2006).

The crude alkaloids from Guatteria australis were active against K1 strain of Plasmodium falciparum with an IC(50)=0,3 microg $/ \mathrm{ml}$. The alkaloid fraction from $G$. australis had antiplasmodial activity with $\mathrm{IC}(50)=5 \mathrm{microg} / \mathrm{ml}$ (Fischer et al., 2004).

Several plant-derived drugs, such as rivastigmine and galanthamine, inhibit $\mathrm{AChE}$, hence increasing the endogenous levels of acetylcholine to boost cholinergic neurotransmission (Lopez et al., 2002). Although plant alkaloids are best known for inhibiting AChE enzyme, recent studies indicate new classes of AChE-inhibiting compounds, such as essential oils (Miyazawa et al., 1997; Perry et al., 2000; Savelev et al., 2004), coumarins (Rollinger et al., 2004; Miyazawa et al., 2001), flavonoid glycosides (Hillhouse et al., 2004), stilbene oligomers and xanthones (Urbain et al., 2004; Howes et al., 2003). Barbosa-Filho et al. (2006) showed in a review that 309 plants belong to 92 botanical families were tested against acetylcholinesterase inhibition whereas 156 of them were active (ca 50\%). Presently, the use of inhibitors of acetylcholinesterase still seems to be the most efficient approach to treat the symptoms of neurodegenerative diseases, such as Alzheimer disease (Viegas et al., 2004).

Of the 17 species analysed, 12 showed anticholinesterasic activity by the TLC assay. However, only three species had higher than 50\% inhibitory effect on acetylcholinesterase, Tetrastylidium grandifolium (stems), Sloanea guianensis (leaves and stems) and Chrysophyllum flexuosum (stems). From the leaves of the latter three triterpene lactones have already been isolated: butanolide [2,3]- $\beta$-amirine, butanolide [2,3]- $\beta$-amirine and butanolide-[2,3]-lupeol. However, no report on acetylcholinesterase inhibiting activity has been described for this species (Marqui et al., 2006).

\section{CONCLUSION}

The therapeutic arsenal for the treatment of some diseases as skin mycoses, cancer and Alzheimer disease is limited and very expensive for the last two of them. Of the 34 extracts from 17 plant species assayed, 22 showed some biological activity. Some of these species have already been analysed for chemical constituents, some of which potentially bearing biological activity. As the present assays were performed with crude extracts, it is now necessary to perform this evaluation bio-guided fractionation of the active extracts which are now in our laboratories. Thus, the Brazilian biodiversity holds a tremendous resource of new products, which has still hardly been explored. Its great potential come only be exploited by chemical prospecting of nature's genetically encoded combinatorial library.

\section{ACKNOWLEDGMENTS}

The RS321N, rad52Y, and RAD+ strains of Saccharomyces cerevisiae were kindly donated from Dr. David G. I. Kingston (Virginia Polytechnic Institute and State University) and Dr. Randall K. Johnson (SmithKline Beecham Pharmaceuticals).

This work was funded by grants by FAPESP (Proc. 2003/02176-7) and CAPES. This work was also supported by the Fundação de Amparo à Pesquisa do Estado de São Paulo (FAPESP) within the BIOTA/ FAPESP - The Biodiversity Virtual Institute Program (http:/ /www.biotasp.org.br, 2006). M. C. M. Young, V. S. Bolzani and S. M. C. Dietrich are grateful to CNPq for research fellowships. Elaine Monteiro CardosoLopes thanks PRODOC/CAPES for providing a postdoctoral fellowship through the graduate programme on "Biodiversidade Vegetal e Meio Ambiente" of Instituto de Botânica (São Paulo).

\section{REFERENCES}

Barbosa-Filho JM, Medeiros KCP, Diniz MFFM, Batista LM, Athayde-Filho PF, Silva MS, Cunha, EVL, Almeida JRGS, Quintans-Júnior LJ 2006. Natural products inhibitors of the enzyme acetylcholinesterase. Rev Bras Farmacogn 16: 258-285.

Barros F, Fiuza de Mello MMR, Chiea SAC, Kirizawa M, Wanderley MGL, Jung-Mendaçolli SL 1991. Caracterização geral da vegetação e listagem das espécies ocorrentes. In: Fiuza de Mello, M.M.R., Barros, F. de, Wanderley, M. das G.L., Kirizawa, M., Jung-Mendaçolli, S.L., Chiea, S.A.C. (Eds.), Flora fanerogâmica da Ilha do Cardoso. São Paulo: Hucitec, v. 1, p. 184.

Di Stasi LC, Oliveira GP, Carvalhaes MA, Queiroz-Junior M, Tien OS, Kakinami SH, Reis MS 2002. Medicinal plants popularly used in the Brazilian Tropical 
Atlantic Forest. Fitoterapia 73: 69-91.

Ellman GL, Courtney KD, Andres VJr, Featherstone RM 1961. A new and rapid colorimetric determination of acetylcholinesterase activity. Biochem Pharmacol 7: 88-95.

Falcão MJC, Pouliquem YBM, Lima MAS, Gramosa NV, Costa-Lotufo LV, Militão GCG, Pessoa C, Moraes MO, Silveira ER 2005. Cytotoxic flavonoids from Platymiscium floribundum. J Nat Prod 68: 423-426.

Fischer DC, Amorim GNC, Bachiega D, Carvalho CS, Lupo FN, Bonotto SV, Alves MO, Yogi A, Santi SM, Ávila PE, Kirchgatter K, Moreno PR 2004. In vitro screening for antiplasmodial activity of isoquinoline alkaloids from Brazilian plant species. Acta Tropica 92: 261-266.

Fiuza de Mello MMR, Mantovani W 1994. Composição florística e estrutura de trecho de Mata Atlântica de encosta, na Ilha do Cardoso (Cananéia, SP, Brasil). Boletim do Instituto de Botânica 9: 107-158.

Gunatilaka AAL, Samaranayake G, Kingston DGI, Hoffmann G, Johnson RK 1992. Bioactive ergost5-ene-3 $\beta, 7 \alpha$-diol derivatives from Pseudobersama mossambicensis. J Nat Prod 55: 1648-1654.

Hillhouse BJ, Ming DS, French CJ, Towers GHN 2004. Acetylcholine esterase inhibitors in Rhodiola rosea. Pharm Biol 42: 68-72.

Homans AL, Fuchs A 1970. Direct bioautography on thin-layer chromatograms as a method for detecting fungitoxic substances. J Chromatogr 51: 327-329.

Howes MJR, Perry NSL, Houghton PJ 2003. Plants with traditional uses and activities, relevant to the management of Alzheimer's disease and other cognitive disorders. Phytother Res 17: 1-18.

http://www.biota.org.br, accessed in November 2006.

Lopez S, Bastida J, Viladomat F, Codina C 2002. Acetylcholinesterase inhibitory activity of some Amaryllidaceae alkaloids and Narcissus extracts. Life Sci 71: 2521-2529.

Marqui SR, Santos LA, Bolzani VS, Silva DHS 2006. Lactonas triterpênicas das folhas de Chrysophyllum flexuosum (Sapotaceae). XXIX Reunião Anual da Sociedade Brasileira de Química. Águas de Lindóia, Brasil.

Marston A, Kissling J, Hostettmann K 2002. A rapid TLC bioautographic method for the detection of acetylcholinesterase and butyrylcholinesterase inhibitors in plants. Phytochem Analysis 13: 51-54.

Militão GC, Jimenez PC, Wilke DV, Pessoa C, Falcão MJ, Souza-Lima MA, Silveira ER, Moraes MO, Costa-Lotufo LV 2005. Antimitotic properties of pterocarpans isolated from Platymiscium floribundum on sea urchin eggs. Planta Med 71: 683-685.

Militão GC, Dantas IN, Pessoa C, Falcão MJ, Silveira ER, Lima MA, Curi R, Lima T, Moraes MO, Costa-Lotufo LV 2006. Induction of apoptosis by pterocarpans from Platymiscium floribundum in HL-60 human leukemia cells. Life Sci 78: 2409-2417.

Miyazawa M, Watanabe H, Kameoka H 1997. Inhibition of acetylcholinesterase activity by monoterpenoids with a p-menthane skeleton. J Agric Food Chem 45: 677-679.

Miyazawa M, Tougo H, Ishihara M 2001. Inhibition of acetylcholinesterase activity by essential oil from Citrus paradise. Nat Prod Lett 15: 205-210.
Myers N, Mittermeier RA, Mittermeier CG, Fonseca GAB, Kent J 2000. Biodiversity hotspots for conservation priorities. Nature 403: 853-858.

Perry NSL, Houghton PJ, Theobald A, Jenner P, Perry EK 2000. In vitro inhibition of human erythrocyte acetylcholinesterase by Salvia lavandulaefolia essencial oil and constituent terpenes. J Pharm Pharmacol 52: 895-902.

Rahalison L, Hamburger M, Monod M, Frenk E, Hostettmann $\mathrm{K}$ 1994. Antifungal tests in phytochemical investigations comparison of bioautographic methods using phytopatogenic and human pathogenic fungi. Planta Med 60: 41-44.

Rhee IK, van de Meent M, Ingkaninan K, Verpoorte R 2001. Screening for acetylcholinesterase inhibitors from Amaryllidaceae using silica gel thin-layer chromatography in combination with bioactivity staining. J Chromatogr A 915: 217-223.

Rizzini CT 1979. Tratado de fitogeografia do Brasil: aspectos sociológicos e florísticos. São Paulo: EDUSP e Editora HUCITEC, p.374.

Rollinger JM, Hornick A, Langer T, Stuppner H, Prast H 2004. Acetylcholinesterase inhibitory activity of scopolin and scopoletin discovered by virtual screening of natural products. J Med Chem 47: 6248-6254.

Savelev SU, Okello EJ, Perry EK 2004. Butyryl- and acetylcholinesterase inhibition activities in essential oils of Salvia species and their constituents. Phytother Res 18: 315-324.

Trevisan MTS, Macedo FVV 2003. Seleção de plantas com atividade anticolinesterase para tratamento da doença de Alzheimer. Quim Nova 26: 301-304.

Urbain A, Marston A, Queiroz EF, Ndjoko K, Hostettmann $\mathrm{K}$ 2004. Xanthones from Gentiana campestris as new acetylcholinesterase inhibitors. Planta Med 70: 1011-1014.

Viegas CJr, Bolzani VS, Furlan M, Fraga CAM, Barreiro EJ 2004. Produtos naturais como candidatos a fármacos úteis no tratamento do Mal de Alzheimer. Quim Nova 27: 655-660.

Vieira RF 1999. Conservation of medicinal and aromatics plants in Brazil. In: J. Janick (ed.). Perspectives on new crops and new uses. Alexandria: ASHS Press, p. 152-159. 